\title{
THE QUALITATIVE AND QUANTITATIVE STRUCTURE OF THE CAUSES OF OCCUPATIONAL ACCIDENTS ON CONSTRUCTION SCAFFOLDING
}

\author{
T. NOWOBILSKI ${ }^{1}$, B. HOLA ${ }^{2}$
}

\begin{abstract}
The article presents the results of research, the aim of which was to determine the qualitative and quantitative structure of the causes of accidents that were a result of falling from scaffolding. An original methodology for the classification of accidents with regards to their causes was developed and was based on cluster analysis. An example of using the proposed methodology is provided. 187 post-accident protocols of occupational accidents involving construction scaffolding, which occurred between 2010 and 2017 in selected Polish voivodeships, were analyzed. Afterwards, the matrix of accident causes, for which the calculations were made, was created. Five subsets of accidents were obtained and the accidents were classified to a subset with similar causes.
\end{abstract}

Keywords: Classification of accidents, classification methodology, construction scaffolding, cluster analysis, causes of accidents

\section{INTRODUCTION}

The construction industry is one of the most dangerous branches of the economy in the world [1]. This is due to the impact of many factors on occupational safety $[2,3,4]$, including those related to the conditions of implementing construction works, the type of carried out works, the type of used equipment, etc. As can be seen in current research, a significant amount of accidents in the

\footnotetext{
${ }^{1}$ MSc Eng., Wroclaw University of Science and Technology, Faculty of Civil Engineering, Department of Technology and Management in Civil Engineering, Wybrzeze Wyspianskiego 27, 50-370 Wroclaw, e-mail: tomasz.nowobilski@pwr.edu.pl

${ }^{2}$ Prof. WUST, PhD, Eng., Wroclaw University of Science and Technology, Faculty of Civil Engineering, Department of Technology and Management in Civil Engineering, Wybrzeze Wyspianskiego 27, 50-370 Wroclaw, e-mail: bozena.hola@pwr.edu.pl
} 
construction industry is related to working at heights, including construction scaffoldings [5]. Work at these workstations carries a high occupational risk. This is influenced by many factors, including technical, organizational and human factors [6], climatic conditions $[7,8,9]$, as well as others. In order to reduce the number of accidents on construction scaffolding, it is necessary to recognize the phenomenon and, in particular, to identify the main causes that contribute to the accidents.

The aim of the conducted research was to obtain information on the qualitative and quantitative structure of the causes that result in the largest number of occupational accidents involving construction scaffolding. The formulated main objective requires the achievement of intermediate goals, which include the obtaining of information on occupational accidents involving construction scaffolding, and also the classification of accidents to subsets with similar causes. The problem was solved using the data mining method - cluster analysis that is available in Statistica software.

\section{TEST METHODOLOGY}

The tests and analyzes were carried out in accordance with the methodology presented in Figure 1.

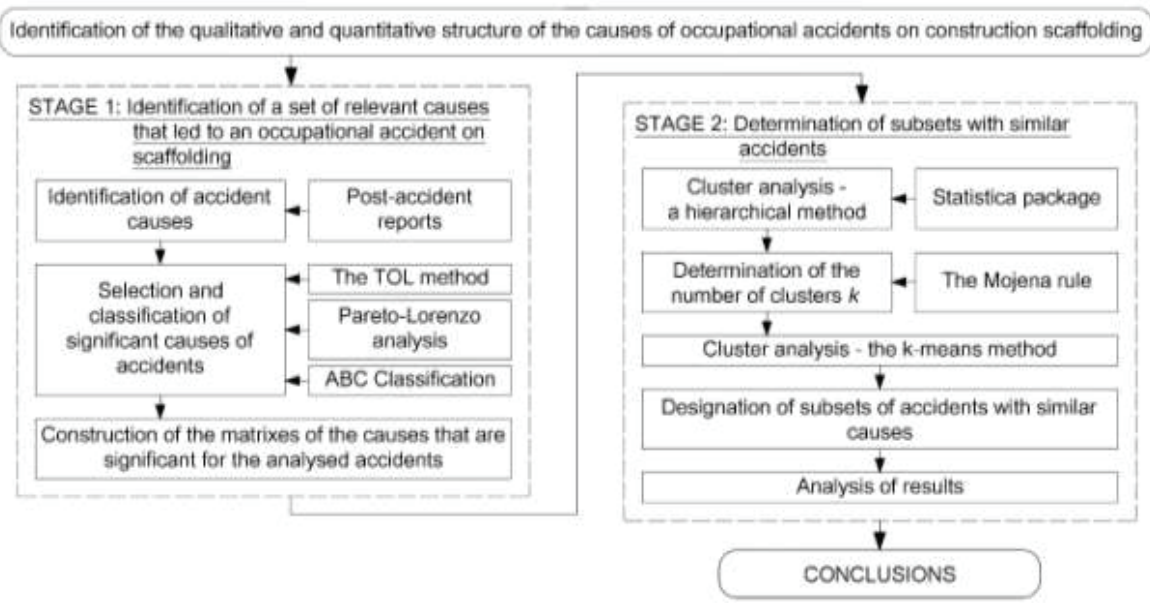

Fig. 1. Scheme of research methodology

Every occupational accident is a result of many causes. Information on the causes of accidents can be obtained, among others, from post-accident protocols. In the case of work on scaffolding, the causes of accidents may involve deficiencies and irregularities in the construction of the scaffolding, improper organization of work on the scaffolding, a lack of medical tests that permit 
work at heights, etc. In Poland, TOL methodology is one of the most widespread methods of classifying the causes of occupational accidents [10]. It assumes that each accident is the result of three types of causes, namely: technical (T), organizational (O) and human (L). Additional significant causes, less significant causes, as well as irrelevant ones can be distinguished in each generic group. In order to identify the significance of causes in each generic group, the authors of publication [11] propose the use of Pareto-Lorenz analysis and ABC classification [12, 13].

The occurrence of the cause of an accident can be described in the form of binary variable $0-1$. The value 1 indicates the occurrence of a given cause, while the value 0 means that the cause did not occur.

The set of all analyzed accidents is characterized by a matrix of causes, which is given by the formula:

$$
A_{V}=\left[\begin{array}{ccccccccc}
T_{1,1} & \ldots & T_{n, 1} & \ldots & O_{n, 1} & \ldots & L_{n, 1} & \ldots & L_{N, 1} \\
T_{1,2} & \ldots & T_{n, 2} & \ldots & O_{n, 2} & \ldots & L_{n, 2} & \ldots & L_{N, 2} \\
\vdots & \vdots & \vdots & \vdots & \vdots & \vdots & \vdots & \vdots & \vdots \\
T_{1, v} & \ldots & T_{n, v} & \ldots & O_{n, v} & \ldots & L_{n, v} & \ldots & L_{N, v} \\
\vdots & \vdots & \vdots & \vdots & \vdots & \vdots & \vdots & \vdots & \vdots \\
T_{1, V} & \ldots & T_{n, V} & \ldots & O_{n, V} & \ldots & L_{n, V} & \ldots & L_{N, V}
\end{array}\right]
$$

where:

$v$ - is the accident number $(v=1,2,3, \ldots, V)$,

$n$ - is the accident cause number $(n=1,2,3, \ldots, N)$.

The resulting set of causes is the basis for the determination of subsets of accidents, which are caused by a similar set of causes. In order to define such subsets, the use of cluster analysis was proposed $[14,15,16]$. The criterion for assessing the affiliation of an object to a given subset is the measure of similarity. In practical considerations, this is a function of the "improbability" of objects. This means that if the distance between objects $O_{a}$ and $O_{b}$ is greater than the distance between objects $O_{a}$ and $O_{c}$, then object $O_{a}$ is more "unlike" object $O_{b}$ than it is to object $O_{c}$. Consequently, this leads to the situation where objects $O_{a}$ and $O_{c}$ can create a cluster because they are more "similar" to each other. In the case of qualitative data analysis, the authors propose to 
determine the distance measure using percentage non-compliance [14]. The general formula of the distance calculated using percentage non-compliance takes the following form:

$$
d\left(O_{a}, O_{b}\right)=\frac{\text { number of all pairs where: } P_{a, n} \neq P_{b, n}}{\text { number of all pairs }}
$$

where:

$O_{a}, O_{b}$ - assessed objects - occupational accidents a and $b$, where $a \neq b$, and $a, b \in\{v\}$,

$P_{a, n}, P_{b, n}$ - values of individual parameters that describe the analyzed accidents $a$ and $b$, where $a \neq b$;

$a, b \in\{v\} ; n=1,2,3, \ldots, N$ and $P_{a, n}, P_{b, n} \in\{0,1\}$.

In the analyzed task, objects refer to individual accidents. The method of hierarchical cluster analysis, and also the agglomeration technique of grouping and binding objects using the Ward method [17], which results in the dendrogram, is proposed in order to determine the number of clusters. Depending on the location of cutting off the branch of the dendrogram, a variable number of clusters is obtained $[18,19,20]$. According to [14], the cut-off location can be determined using various methods, including the Mojena rule [21]. According to this method, the place of division is the achievement of such a binding distance for which the inequality given by the following formula is fulfilled:

$$
d_{i}+1>M+k_{M} \cdot s_{d}
$$

where:

$d_{0}, d_{1}, \ldots, d_{n-1}-$ distance between bonds for subsequent stages: $n, n-1, \ldots, 1$,

$M$ - average value of the distance between bonds,

$s_{d}-$ standard deviation $d_{i}$,

$k_{M}$ - a constant value ranging from 2,75 to 3,50 .

The next step is to assign the analyzed accidents to individual clusters, i.e. the determination of subsets of accidents that are similar with regards to their causes. For this purpose, the authors propose the use of the $k$-means grouping method. Analysis of the obtained results will allow the qualitative and quantitative structure of the causes of occupational accidents involving construction scaffolding to be determined. 


\section{THE APPLICATION OF THE PROPOSED METHODOLOGY}

Occupational accidents, which occurred between 2010 and 2017 in the following voivodships: Dolnoslaskie, Lubelskie, Lodzkie, Mazowieckie and Wielkopolskie, were subjected to analysis. On its basis, 187 accidents involving construction scaffolding were identified, for which a set of 1,198 causes was determined. The naming of the detailed causes of accidents included in Table 1, which was adopted for the purpose of the analysis, is identical to the nomenclature used in statistical accident cards. From the set of identified organizational, human and technical causes, important causes that were most often identified in accidental protocols and selected on the basis of ParetoLorenz analysis and $\mathrm{ABC}$ classification $[12,13]$ were selected for further analysis.

The next stage of the research involved the determination of sets of similar accidents. The matrix of causes $A_{V}$ was built for the set of all accidents. It was the basis for the calculations when using the hierarchical cluster analysis method, as a result of which the dendrogram was obtained. The analysis of the dendrogram, with the assumption of the constant $k_{M}=3,00$ in the applied Mojena method, allowed the expected number of clusters $k=5$ to be determined. Accidents were then grouped into 5 subsets marked as G1 - G5 using the k-means method. The subsets varied with the number and type of causes - Table 1 . This table provides causes that occurred in more than $50 \%$ of accidents that were qualified for a given set.

Table 1. Accident causes

\begin{tabular}{|c|c|c|c|c|c|c|}
\hline \multicolumn{2}{|l|}{ Subgroups of accidents } & G1 & G2 & G3 & G4 & G5 \\
\hline \multicolumn{2}{|l|}{ Size of a subset of accidents } & 29 & 29 & 30 & 31 & 68 \\
\hline Cause name & $\begin{array}{c}\text { Cause } \\
\text { designation }\end{array}$ & \multicolumn{5}{|c|}{$\begin{array}{c}\text { Share of causes in a particular subgroup } \\
\text { of accidents }\end{array}$} \\
\hline \multicolumn{7}{|c|}{ TECHNICAL CAUSES } \\
\hline $\begin{array}{l}\text { Design defects of scaffolding that are a source } \\
\text { of a hazard }\end{array}$ & $\mathrm{T} 1.1$ & 0.000 & 0.034 & 0.267 & 0.065 & 0.015 \\
\hline Inappropriate spatial structure of scaffolding & $\mathrm{T} 1.2$ & 0.207 & 0.897 & 0.167 & 0.032 & 0.206 \\
\hline Incorrect stability of scaffolding & $\mathrm{T} 1.4$ & 0.207 & 0.724 & 0.033 & 0.226 & 0.235 \\
\hline A lack of or incorrect safety devices & $\mathrm{T} 1.5$ & 0.690 & 0.793 & 0.267 & 0.161 & 0.353 \\
\hline A lack of or improper collective protection measures & $\mathrm{T} 1.6$ & 0.069 & 0.483 & 0.333 & 1.000 & 0.000 \\
\hline A lack of or incorrect signalling of hazards & $\mathrm{T} 1.8$ & 0.000 & 0.034 & 0.033 & 0.065 & 0.059 \\
\hline The use of substitute materials & $\mathrm{T} 2.1$ & 0.000 & 0.069 & 0.067 & 0.161 & 0.044 \\
\hline
\end{tabular}




\begin{tabular}{|c|c|c|c|c|c|c|}
\hline \multicolumn{7}{|c|}{ ORGANIZATIONAL CAUSES } \\
\hline Incorrect work division or distribution of tasks & O1.1 & 0.069 & 0.069 & 0.100 & 0.097 & 0.059 \\
\hline A lack of supervision & 01.3 & 0.517 & 0.517 & 0.433 & 0.677 & 0.485 \\
\hline Incorrect coordination of collective works & O1.4 & 0.103 & 0.172 & 0.000 & 0.000 & 0.059 \\
\hline A lack of instructions on how to use a material factor & O1.6 & 0.103 & 0.414 & 0.433 & 0.161 & 0.176 \\
\hline $\begin{array}{l}\text { Permission to use a material factor without the } \\
\text { required inspections and supervisions }\end{array}$ & O1.7 & 0.379 & 0.793 & 0.467 & 0.484 & 0.162 \\
\hline $\begin{array}{l}\text { Acceptance of deviations from the provisions and } \\
\text { rules of occupational health and safety } \\
\text { by supervising people }\end{array}$ & $\mathrm{O} 1.8$ & 0.793 & 0.586 & 0.233 & 0.258 & 0.088 \\
\hline Inadequate professional preparation of an employee & O1.9 & 0.345 & 0.379 & 0.133 & 0.323 & 0.250 \\
\hline $\begin{array}{l}\text { A lack of or improper training in the field } \\
\text { of occupational health and safety }\end{array}$ & O1.10 & 0.276 & 0.448 & 1.000 & 0.097 & 0.103 \\
\hline $\begin{array}{l}\text { Acceptance by supervisors of the use } \\
\text { of inappropriate technology }\end{array}$ & O1.11 & 0.069 & 0.138 & 0.033 & 0.000 & 0.118 \\
\hline $\begin{array}{l}\text { Allowing an employee to work with medical } \\
\text { contraindications or without medical examinations }\end{array}$ & $\mathrm{O} 1.12$ & 0.103 & 0.276 & 0.600 & 0.097 & 0.059 \\
\hline Inadequate passages and paths towards objects & $\mathrm{O} 2.2$ & 0.276 & 0.483 & 0.233 & 0.161 & 0.088 \\
\hline $\begin{array}{l}\text { Inappropriate placement and storage of work items } \\
\text { (raw materials, semi-finished products, products etc.) }\end{array}$ & $\mathrm{O} 2.3$ & 0.034 & 0.241 & 0.000 & 0.000 & 0.088 \\
\hline A lack of personal protective equipment & $\mathrm{O} 2.5$ & 0.069 & 0.000 & 0.467 & 0.097 & 0.059 \\
\hline \multicolumn{7}{|c|}{ HUMAN CAUSES } \\
\hline $\begin{array}{l}\text { Using a material factor that is unsuitable for a given } \\
\text { job }\end{array}$ & L1.1 & 0.103 & 0.069 & 0.000 & 0.032 & 0.059 \\
\hline Improper protection of a material factor & L1.4 & 0.034 & 0.103 & 0.000 & 0.097 & 0.015 \\
\hline Improper gripping/holding of a material factor & $\mathrm{L} 1.7$ & 0.000 & 0.069 & 0.000 & 0.000 & 0.044 \\
\hline $\begin{array}{c}\text { A lack of using personal protective equipment by an } \\
\text { employee }\end{array}$ & $\mathrm{L} 2.1$ & 0.621 & 0.379 & 0.200 & 0.419 & 0.176 \\
\hline $\begin{array}{l}\text { Performing work that is not included in the scope of } \\
\text { the employee's duties }\end{array}$ & L3.1 & 0.103 & 0.034 & 0.100 & 0.065 & 0.147 \\
\hline $\begin{array}{l}\text { Moving around, passing through or staying } \\
\text { in unauthorized places }\end{array}$ & $\mathrm{L} 3.2$ & 0.414 & 0.103 & 0.167 & 0.000 & 0.118 \\
\hline $\begin{array}{l}\text { Performing activities without removing the hazard } \\
\text { (e.g. not turning off a machine, not switching off the } \\
\text { voltage) }\end{array}$ & L3.4 & 0.034 & 0.000 & 0.033 & 0.032 & 0.044 \\
\hline $\begin{array}{l}\text { Consumption of alcohol, narcotic drugs } \\
\text { or psychotropic substances }\end{array}$ & L4.5 & 0.069 & 0.172 & 0.100 & 0.290 & 0.191 \\
\hline A lack of knowledge about a hazard & L5.1 & 0.103 & 0.103 & 0.133 & 0.000 & 0.029 \\
\hline $\begin{array}{l}\text { A lack of knowledge about occupational health and } \\
\text { safety rules and regulations }\end{array}$ & L5.2 & 0.069 & 0.069 & 0.200 & 0.000 & 0.000 \\
\hline Disregarding danger (bravery, risk) & L5.3 & 0.897 & 0.000 & 0.167 & 0.129 & 0.103 \\
\hline Insufficient attention when performing an operation & L5.5 & 0.034 & 0.103 & 0.067 & 0.161 & 0.191 \\
\hline Being surprised by an unexpected event & L5.6 & 0.345 & 0.069 & 0.100 & 0.097 & 0.206 \\
\hline
\end{tabular}


The values included in Table 1 describe the participation of a given cause in a subset of accidents, e.g. the G4 subset contains 31 accidents. The dominating causes in this subset are: a lack of or inappropriate collective protection measures and also a lack of supervision. The most numerous set G5 contains 68 accidents. The causes of accidents in this group are characterized by very high dispersion, which makes the indication of the dominant causes difficult. However, it should be noted that the causes that most often result in accidents in this group are: a lack of supervision, a lack of or inappropriate safety devices, as well as the insufficient professional preparation of an employee.

\section{CONCLUSIONS}

In the analysis of the accident rate phenomenon, knowledge about the causes that most often lead to accidents is crucial. The article proposes a methodology for the classification of occupational accidents that involve construction scaffolding, which is based on knowledge about the causes that led to their occurrence. Based on the conducted research and analyses, the following conclusions were made:

1. The causes of accidents can be classified into the following generic groups: technical, organizational and human. Every occupational accident is caused by at least several causes that belong to these generic groups. The relevant causes that very often lead to an accident can be identified in each generic group of causes based on the analysis of the causes from a large set of accidents.

2. The built matrix of causes can be the basis for grouping accidents into subsets that involve accidents caused by similar causes. Such grouping can be carried out using the methodology proposed in the article, which is based on cluster analysis.

3. Based on the conducted calculations, 5 subsets containing accidents that are similar with regards to their causes were obtained. The G1 set has 29 accidents. The dominating causes are as follows: a lack of or inappropriate safety devices, a lack of supervision, acceptance by supervisors of deviations from the provisions and principles of occupational health and safety, a lack of using personal protective equipment by an employee, and also the disregarding of risk (bravery, risk). The G2 set consists of 29 accidents. The dominating causes are as follows: improper spatial structure of scaffolding, improper stability of scaffolding, a lack of or incorrect safety devices, a lack of supervision, permitting a material factor to be used without the required 
inspections and supervisions, and also acceptance by supervisors of deviations from the provisions and principles of occupational health and safety. The G3 set consists of 30 accidents. The dominating causes in this set are as follows: a lack of or incorrect training in the field of occupational health and safety, and also allowing an employee to work with medical contraindications or without medical examinations. The G4 set consists of 31 accidents and the dominating causes are as follows: a lack of or inappropriate collective protection measures and also a lack of supervision. The G5 set has 68 accidents. The causes of accidents in this set are characterized by a very large dispersion, which is why the indication of unambiguous causes is difficult. However, it should be noted that the causes that most often cause accidents in this set are: a lack of supervision, a lack of or inappropriate safety devices, and also insufficient professional preparation of an employee.

4. The proposed methodology can be applied in the area of scientific research and also engineering practice. The obtained research and analysis results can be the basis for the classification and comparison of other sets of accidents that are characteristic for construction technologies, construction machines or constructed building objects. The practical aspect of the proposed methodology is connected with the possibility of formulating conclusions that may be important for the improvement of occupational safety in the construction industry. This is due to the identification of the causes that most often result in accidents, and in turn the indication of appropriate prophylactic solutions.

5. In the research conducted by the authors, information on the number of causes in individual sets will be used to estimate the probability of the occurrence of an accident that is a result of a given cause or set of causes. The results of these estimations can be used in further research on occupational risk assessment in the construction industry.

The article is the result of the implementation by the authors of research project No. 244388 "Model of the assessment of risk of the occurrence of building catastrophes, accidents and dangerous events at workplaces with the use of scaffolding", financed by NCBiR within the framework of the Programme for Applied Research on the basis of contract No. PBS3/A2/19/2015. 


\section{REFERENCES}

1. International Labour Organization, "Safety and Health at Work: A Vision for Sustainable Prevention", Frankfurt, 2014.

2. B. Hoła, T. Nowobilski, I. Szer, J. Szer, "Identification of factors affecting the accident rate in the construction industry", Procedia Engineering, 2017, vol. 208, pp. 35-42.

3. B. Hoła, T. Nowobilski, J. Rudy, K. Czarnocki, "An analysis of the influence of selected factors on the accident rate in the construction industry", Czas. Tech., vol. 6, no. June, pp. 95-102, 2018.

4. W. Drozd, "Examination of the features of a construction site and their impact on the safety of conducting construction works on non-linear facilities". Cracow: Monographs of the Cracow University of Technology, series Inżynieria Lądowa, 2017.

5. B. Hoła, T. Nowobilski, J. Rudy, E. Błazik-Borowa, "Dangerous events related to the use of scaffolding", Czas. Tech., vol. 7, no. July 2017, 2017.

6. M. Szóstak, "The application of cluster analysis to identify the occupational profile of people injured in accidents in the Polish construction industry", IOP Conf. Ser. Mater. Sci. Eng., vol. 456, pp. 1-8, 2018.

7. I. Szer, E. Błazik Borowa, J. Szer, "The Influence of Environmental Factors on Employee Comfort Based on an Example of Location Temperature", Arch. Civ. Eng., vol. LXIII, no. 3, 2017.

8. M. Jabłoński, I. Szer, J. Szer, "Probability of occurrence of health and safety risks on scaffolding caused by noise exposure”, J. Civ. Eng. Manag., vol. 24, no. 6, pp. 437-443, 2018.

9. I. Szer, J. Szer, K. Czarnocki, E. Błazik Borowa, “Apparent Temperature Distribution on Scaffoldings during Construction Works”, Int. J. Med. Heal. Sci., vol. 5, no. 3, pp. 81-87, 2018.

10. Department of Statistical, "Wypadki przy pracy w 2015 r.", Warsaw, Poland: Central Statistical Office, 2016.

11. A. Hoła, M. Sawicki, M. Szóstak, "Methodology of Classifying the Causes of Occupational Accidents Involving Construction Scaffolding Using Pareto-Lorenz Analysis”, Appl. Sci., vol. 8, no. 1, p. 48, Jan. 2018.

12. C.-W. Chu, G.-S. Liang, C.-T. Liao, "Controlling inventory by combining ABC analysis and fuzzy classification”, Comput. Ind. Eng., vol. 55, no. 4, p. 841-851 Computers \& Industrial Engineering, 2008.

13. D. Dhoka, D. Y. L. Choudary, "ABC Classification for Inventory Optimization”, IOSR J. Bus. Manag., vol. 15 , no. 1, pp. 38-41, 2013.

14. A. Stanisz, "An easy course of statistics with the use of STATISTICA PL using examples from medicine, Volume 3: Linear and nonlinear models", Cracow, 2007.

15. S. Wierzchoń and M. Kłopotek, "Cluster analysis algorithms", Warsaw: WNT Publisher, 2015.

16. A. Leśniak, M. Juszczyk, G. Piskorz, "Delays factors of a completion construction project aggregation with the use of cluster analysis", Mater. Bud., vol. 10, pp. 62-65, 2018.

17. J. H. J. Ward, "Hierarchical Grouping to Optimize an Objective Function", J. Am. Stat. Assoc., vol. 58, no. 301, pp. 236-244, 1963.

18. T. Nowobilski, I. Bagińska, K. Gawron, "Classification of Polish voivodeships with regards to the accident rate in the construction industry", in MATEC Web of Conferences, 2018, vol. 04007, pp. 1-8.

19. B. Hola, T. Nowobilski, "Classification of economic regions with regards to selected factors characterizing the construction industry", Sustain., vol. 10, no. 5, 2018.

20. B. Hoła, T. Nowobilski, "Classification of Polish voivodeships with regards to the selected indicators that characterize the construction industry", Sci. c Rev. - Eng. Environ. Sci., Vol. 27, no. 3, pp. 310-318, 2018.

21. R. Mojena, "Hierarchical grouping methods and stopping rulet: an evaluation", Comput. J., vol. 20, no. 4, pp. 359-363, 1977.

\section{LIST OF FIGURES AND TABLES:}

Fig. 1. Scheme of research methodology

Rys. 1. Schemat metodyki badan

Tab. 1. Accident causes

Tab. 1. Przyczyny wypadków 


\title{
STRUKTURA JAKOŚCIOWA I ILOŚCIOWA PRZYCZYN WYPADKÓW PRZY PRACY NA RUSZTOWANIACH BUDOWLANYCH
}

\begin{abstract}
Keywords: Klasyfikacja wypadków, metodyka klasyfikacji, rusztowania budowlane, analiza skupień, przyczyny wypadków
\end{abstract}

\section{STRESZCZENIE:}

Branża budowlana zaliczana jest do jednej z najbardziej niebezpiecznych gałęzi gospodarki na świecie. Spowodowane jest to wpływem na bezpieczeństwo pracy wielu czynników, m.in. związanych z warunkami realizacji obiektów budowlanych, rodzajem prowadzonych robót, rodzajem stosowanych urządzeń, itp. Jak pokazują dotychczasowe badania, znaczna część wypadków w budownictwie związana jest z pracą na wysokości, w tym na rusztowaniach budowlanych. Praca na tych stanowiskach obarczona jest dużym ryzykiem zawodowym. Aby ograniczyć liczbę wypadków na rusztowaniach budowlanych konieczne jest właściwe rozpoznanie zjawiska, a zwłaszcza zidentyfikowanie głównych przyczyn sprzyjających powstawaniu wypadków.

Celem prowadzonych badań było uzyskanie informacji o strukturze jakościowej i ilościowej przyczyn powodujących największą liczbę wypadków przy pracy z udziałem rusztowań budowlanych. Sformułowany cel główny wymaga osiągnięcia celów pośrednich, do których zaliczono: pozyskanie informacji o wypadkach przy pracy z udziałem rusztowań budowlanych oraz dokonanie klasyfikacji posiadanego zbioru wypadków na podzbiory skupiające wypadki o podobnych przyczynach. Do rozwiązania zagadnienia wykorzystano metodę eksploracji danych - analizę skupień, dostępną w oprogramowaniu Statistica. Autorzy artykułu opracowali metodykę klasyfikacji wypadków w aspekcie ich przyczyn przedstawioną na rys.1.

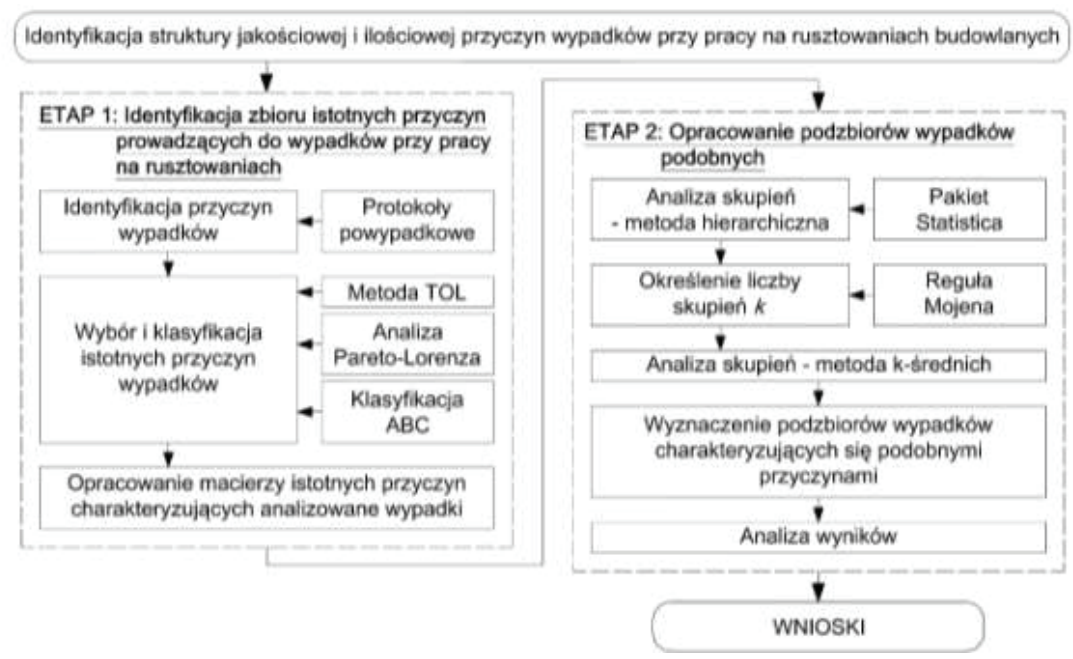

Rys. 1. Schemat opracowanej metodyki badań

W celu weryfikacji metodyki przeprowadzono analizę wypadków przy pracy, które zaistniały w latach od 2010 do 2017 roku, w województwach: dolnośląskim, lubelskim, łódzkim, mazowieckim i wielkopolskim. $\mathrm{Na}$ tej podstawie zidentyfikowano 187 wypadków z udziałem rusztowań budowlanych, dla których określono zbiór 1198 przyczyn. 
Spośród zbioru zidentyfikowanych przyczyn technicznych organizacyjnych i ludzkich, do dalszej analizy, wybrano przyczyny istotne, najczęściej identyfikowane w protokołach powypadkowych.

Następnie określono zbiory wypadków podobnych. Dla zbioru wszystkich wypadków, zbudowano macierz przyczyn istotnych, która była podstawą ich klasyfikacji. Po przeprowadzeniu obliczeń, z wykorzystaniem analizy skupień, przy założeniu stałej $k_{M}=3,00$ w zastosowanej metodzie Mojena, uzyskano 5 podzbiorów wypadków różniących się między sobą liczbą i rodzajem przyczyn. Fragment uzyskanych wyników obejmujących przyczyny techniczne, przedstawiono w Tabeli 1.

Tabela 1. Przyczyny techniczne wypadków

\begin{tabular}{|c|c|c|c|c|c|c|}
\hline \multicolumn{2}{|l|}{ Podgrupy wypadków } & G1 & G2 & G3 & G4 & G5 \\
\hline \multicolumn{2}{|l|}{ Liczebność podzbioru wypadków } & 29 & 29 & 30 & 31 & 68 \\
\hline Nazwa przyczyny & $\begin{array}{c}\text { Oznaczenie } \\
\text { przyczyny }\end{array}$ & \multicolumn{5}{|c|}{$\begin{array}{l}\text { Udział przyczyn w poszczególnych } \\
\text { podgrupach wypadków }\end{array}$} \\
\hline \multicolumn{7}{|c|}{ PRZYCZYNY TECHNICZNE } \\
\hline $\begin{array}{l}\text { Wady konstrukcyjne rusztowania będące źródłem } \\
\text { zagrożenia }\end{array}$ & $\mathrm{T} 1.1$ & 0,000 & 0,034 & 0,267 & 0,065 & 0,015 \\
\hline Niewłaściwa struktura przestrzenna rusztowania & $\mathrm{T} 1.2$ & 0,207 & $\mathbf{0 , 8 9 7}$ & 0,167 & 0,032 & 0,206 \\
\hline Niewłaściwa stateczność rusztowania & $\mathrm{T} 1.4$ & 0,207 & 0,724 & 0,033 & 0,226 & 0,235 \\
\hline Brak lub niewłaściwe urządzenia zabezpieczające & $\mathrm{T} 1.5$ & 0,690 & 0,793 & 0,267 & 0,161 & 0,353 \\
\hline Brak lub niewłaściwe środki ochrony zbiorowej & T1.6 & 0,069 & 0,483 & 0,333 & 1,000 & 0,000 \\
\hline Brak lub niewłaściwa sygnalizacja zagrożeń & T1.8 & 0,000 & 0,034 & 0,033 & 0,065 & 0,059 \\
\hline Zastosowanie materiałów zastępczych & $\mathrm{T} 2.1$ & 0,000 & 0,069 & 0,067 & 0,161 & 0,044 \\
\hline
\end{tabular}

Na podstawie przeprowadzonych badań i analiz sformułowano m. in. następujące wnioski:

1. Na podstawie obliczeń, otrzymano 5 podzbiorów zawierających wypadki podobne pod kątem przyczyn, które je spowodowały. Przykładowo, zbiór G1 liczy 29 wypadków. Dominującymi przyczynami w tym zbiorze są: brak lub niewłaściwe urządzenia zabezpieczające, brak nadzoru, tolerowanie, przez osoby sprawujące nadzór odstępstw od przepisów i zasad bezpieczeństwa i higieny pracy, nieużywanie przez pracownika środków ochrony indywidualnej, lekceważenie zagrożenia (brawura, ryzykanctwo).

2. Proponowana metodyka może być stosowana zarówno w obszarze badań naukowych, jak iw praktyce inżynierskiej. Uzyskane wyniki badań i analiz mogą być podstawą do klasyfikacji i porównywania innych zbiorów wypadków charakterystycznych dla stosowanych w budownictwie technologii, maszyn budowlanych bądź realizowanych obiektów budowlanych. Praktyczny aspekt proponowanej metodyki wiąże się z możliwością formułowania wniosków, które mogą być istotne dla poprawy bezpieczeństwa pracy w budownictwie poprzez wskazanie przyczyn najczęściej powodujących wypadki, a następnie wskazanie właściwych rozwiązań profilaktycznych.

3. W prowadzonych przez autorów badaniach naukowych, informacje o liczności przyczyn w poszczególnych zbiorach będą wykorzystane do szacowania prawdopodobieństwa powstania wypadku spowodowanego poprzez daną przyczynę lub zbiór przyczyn. Wyniki tych oszacowań mogą być wykorzystane w dalszych badaniach dotyczących oceny ryzyka zawodowego w budownictwie. 